\title{
REFLECTIONS ON THE CONTEXT OF THE CHANGE OF WAR
}

\author{
Mihai Marcel NEAG, Lucian ISPAS \\ "Nicolae Bălcescu" Land Forces Academy, Sibiu, Romania \\ mmneag@yahoo.com, ispaslucian04@yahoo.com
}

\begin{abstract}
In order to understand and explain the changes of war in a very complex operational environment and in a continuous transformation, we must anticipate, render in an abstract form and create solutions for successful decisions. The estimates of this communication resulted from a combined analysis of the conditions of war without winners and losers, given that humanity has evolved towards modernity from the perspective of changing the forms of consciousness, reshaping relationships and social structures, technological developments, or reporting the individual to the environment around him. In this context, identifying the relationships between the phenomenon of war and the other aspects (domains) of social life becomes a real challenge.
\end{abstract}

\section{Keywords: information warfare, hybrid threats, operational states, misinformation}

\section{Introduction}

We decided to address this topic for reasons of topicality and the importance of the issues arising from the study of the current operational environment. Therefore, this study proposes to present the novelty in the transformation of society, viewed through the prism of changes of warin an information-driven era, in which the technological advances change the face of warfare and the way in which we prepare for warfare.

The multitude of factors involved in this competition makes modern "information warfare" the most dangerous and unpredictable tool for inducing insecurity, confusion, mistrust and panic among national communities and becomes one of the greatest risks to national security.

It is necessary to analyze the change of the war in the context generated by the pressure of the COVID-19 pandemic, which has economic, social, ecological implications, etc. and it tends to forever change the notions of national, European and global security crises. This issue is part of the general theme "War as change in the current conditions" and the sub-theme "Adaptability of forces in the dynamics of operational states".

The studied models have obviously transmitted to us the analysis methodology used by scientists in the works published over the years, but, in order to obtain new results, a new methodology is needed. The explanation is simple: by using old research tools on the same concepts and theories, it is difficult to obtain completely different and truly new ideas. Consequently, within this paper we have tried to find a unique method of investigation, or at least to improve the currently used ones, with a view to creating conditions that allow us to discover some new elements.

The research methods used are: the deductive method, the cause-effect relationship, the analysis of the content of documents and the descriptive analysis. Our hypotheses directed us towards the trends of the transformation of warfare as a whole, 
in the conditions of its hybridization, from which we have deduced the particularities of the armed combat and described the adaptation of the laws of armed combat. It is imperative that the latter should be adopted gradually, without any shocks.

\section{The dynamics of operational states in hybrid confrontation}

The phrase Hybrid War is a polemological term of a relatively recent date, the first explicit references to it being contained in W. Nemeth's thesis from 2002, but the conceptual approach was developed by $\mathrm{F}$. Hoffman. According to Van Mesel, hybrid warfare can be considered what Clausewitz defined as being total warfare.

We must emphasize that the current hybrid confrontation involves a combination of military and non-military efforts, activating a wide range of actions, from open conventional operations to soft manifestations, with the exacerbation of propaganda activities.

The hybrid confrontation is supported by forces with a particular morphology, having unusual forms of involvement, through a totally special dynamic which corresponds to a sui generis conception of execution. The course of the belligerence takes place in disguise or in plain sight, for the purpose of strategically surprising the opponent, as well as of deceiving the world public opinion regarding the real interests, intentions and manifestations.

It is well-known that the armed actions specific to warfare have a similar development. Thus, the stages of the classical war may have in succession as follows: the shaping of a major dispute between two international actors, defining options regarding the military conflict, establishing armed confrontation between combat units, decreasing the armed confrontation and post-conflict disputes.

Each major conflict had a completely different development, deduced from the general geostrategic framework, the potential in the major areas of confrontation, the interests of the actors, the changes in the overall picture of international alliances or coalitions, as well as due to significant events that were produced. The NATO documents acknowledge the possibility of structuring in five phases: informing, situation analysis, development of response options, planning and execution, and transition to normality [1]. The hybrid warfare can have its own stages. Establishing the role of the participants aims at identifying and moving to carrying out secret preparatory activities, in accordance with the desired involvement and action mechanisms [2]. The content refers to establishing the general purpose and objectives of the hybrid confrontation in relation to the desired final state and the relevant elements of the operational design of the parties, establishing the main effects to be achieved, orchestrating and establishing the content of the main types of operations, elaborating the strategic plan of operations on variants [3], other aspects.

The duration in time isquite long, compared to other phases. It can be carried out continuously or intermittently, for months or even years. Obviously, other measures and actions can be activated. It should be emphasized that there are no essential differences in the aggressor's directions of involvement compared to a conventional conflict.

The offensive phase refers to the integration of the efforts of the various participating institutions and forces in accordance with the concept of confrontation, in order to achieve the desired effects [4]. We will witness the combination of specific military attack elements with non-military ones. Tools and civilian involvement in a highly challenging military context [5] will be widely used.

The stabilization phase refers to the strengthening and consolidation of the results obtained by imposing the new power in the separatist areas [6]. In this phase, the effort will be directed towards consolidating the aspects derived from achieving the general goal, the final state and the proposed objectives, from applying 
the aspects of the operational design in the operational context in the separatist territories.

The advanced technologies being used are to be felt in generating major effects on areas (spheres) of interest (especially complex and cascading effects), exploiting and expanding the vulnerabilities of the opponent, synchronized development of major types of operations. The moral element can influence the emergence of certain critical moments in the military action, or can even determine ways to overcome such moments when they occur.

The essential difference from the traditional actions is materialized by the triggering of forms of armed violence, carried out by radicalized ethnic structures in their own territory, with massive implications of Intelligence structures, Special Operations Forces and secret services. The modern equipment smuggled into the target state will increase the militia's chances of intervention or may be operated by even the little green men/terroris [7].

The successive operational states that the warring parties go through in the hybrid war are moments or sequences of this type of confrontation. Each moment (sequence) has its own specific objectives, forms and ways of development and distinct importance in achieving the final goals/effects of the action [8]. In our opinion, the moments/sequences that compose the successive operational states to which the aggressed state is subjected in the hybrid war arethe following: general destabilization of the country, collapse of population morale and destabilization of society, precipitation of politico-military crises, economic ruination, destruction of infrastructure and state collapse, expanding control over the target areas.

From this perspective, the ways to achieve superiority are oriented in at least two directions: achieving superiority in information and communication technology in troops leadership; ensuring doctrinal flexibility, adaptation and modularity, integrated connectivity, multinational and interagency connectivity and versatility. All of themprovide strength and credibility to the forces. Today, more than ever before, it is obvious that it is not the military dimensions of the competing entities that determine their success, nor their quantity, but their quality, their ability to apply the new technical and technological discoveries in a short period of time.

The contemporary hybrid warfare is a novelty in that it involves obtaining simultaneous success on all "battlefields" that require the presence of populations. It is carried out in populated conflict areas, with the participation of the population, under the eyes of the international community. The conflicts in the vicinity of the Black Sea, the one in Georgia in 2008 and the one in Crimea and Ukraine in 2014, whose main actor was the Russian Federation, demonstrate the contemporaneity of the concept of hybrid confrontation. A hybrid threat is more than the sum of its constituent parts. Countering such threats requires new capabilities as much as new partners, new processes and, above all, new strategic thinking. In our opinion, counteracting the hybrid threats focuses mainly on their understanding, as well as on the innovative use of the existing capabilities, a deep knowledge of the requirements of the laws and principles of modern armed combat, whose influences can in no way be circumvented.

\section{Current guidelines in understanding war}

The new concepts of wagingwarfare were generated by the new technologies and mass industrial production of the $19^{\text {th }}$ and $20^{\text {th }}$ centuries. An important element was the emergence of communication and information transmission channels, in a very fast manner. From "total warfare" we have come to the easy, commercial use of the "psychological warfare", "information warfare/aggression", "warfare of political palaces", "warfare of civilizations".

The operations that are based on summing up the effects represent "a process of 
obtaining the desired strategic result on the opponent, by synergistically, multiplicatively and cumulatively applying the entire range of military and non-military operations, at the tactical, operational and strategic levels" [9].

The network-based warfare foreshadows the dominant features of the war of the future. It uses the current and future technologies with maximum efficiency to increase the parameters of efficiency and effectiveness. Military commanders can benefit from a higher degree of knowledge and understanding of the situation, which can lead to making optimal decisions. The sensors, military and political decisionmakers are constantly interconnected. The data, information, analyses, orders flow in a continuous flux, in accordance to the changes that occur in the reality of the battle space. This produces immediate benefits: from increasing the speed of reaction of the decision act to the more efficient management of human and material resources.

The integrative concept of information operations - INFO OPS - was preceded by the concept of psychological operations PSYOPS -, which is the starting point of information operations. Psychological operations are - from the perspective of American military specialists, as well as of NATO cases, which is included in the conceptual military perspective in Romania - a combat capability, a weapon with a decisive force, which has specialized personnel and specific means of action.

The information warfare is a rapidlyevolving and still vaguely-defined field. The source of both interest and inaccuracy in this area is the so-called information revolution, driven by the rapid continuous evolution of cyberspace, microcomputers and associated information technologies. The end result and the implications of these changes will be a new facet of warfare, with profound influences on traditional military operations, which will fundamentally change the future character of warfare.
The most recent example of global information warfare is the outbreak of the global pandemic crisis in February 2020, caused by the spread of the COVID-19 virus. NATO Secretary-General, Jens Stoltenberg, has warned that, more than ever, NATO needs to be on guard, to see how the pandemic turns into a security threat, a process that could degenerate if Russia or the terrorist groups were trying to take advantage of the pandemic crisis.

Misinformation and fake information have always been a destabilizing feature of outbreaks of infectious diseases. Several factors have made the situation worse. The war of misinformation around the COVID19 pandemic is a constant of the atmosphere in which the world has lived since the onset of the disease.

In many countries around the world, the armed forces are increasingly being called upon to help in a very different war - the campaign against the coronavirus pandemic. Asking for military help is a significant and serious step for a government. It would be a measure of the escalation of the pandemic crisis, but it could help to ensure that the state is fully committed and that all the available resources are mobilized.

The ongoing operations were suspended and the number of troops deployed was significantly reduced. The international effort in Iraq, coordinated by NATO, for the country to train and support its armed forces, has been almost completely diminished. In many societies, when the military takes to the streets, this is a sign of political instability. Different cultures, different countries react to the increased visibility of the armed forces in different ways. But even in the most stable democratic societies, such as those in Western Europe, the deployment of troops is no longer so unusual.

The military must always be prepared for war, just in case. General Sir Nicholas Carter, the head of the British Armed Forces, remarked that the military must be "prepared to fight the war we should be waging, and 
now it is clear that the time has come" [10]. "Europe has been facing the biggest threat to its democracies since World War II, and now, more than ever, we must defend the values and principles we stand for", said Roberta Bonazzi, President of the European Foundation for Democracy [11].

\section{Misinformation - a weapon with unsuspected implications}

Social panic occurs when, in the absence of coherent and current official information, people tend to project negative and catastrophic scenarios. As no one has information about the future, in times of enhanced anxiety, distrust of authorities increases, and public communication becomes chaotic, given the growing number of COVID-19 cases around the world, as well as the unusual volatility in financial markets.

But one thing that seemed to be neverending in 2020 was the chain of fake stories, which were largely aimed at misinforming citizens. They spread through social networks and applications such as WhatsApp, reaching a huge percentage of the population. These initiatives are always driven by dubious reasons, from political interest to provoking social panic, to unethical businesses to the detriment of the people. Fake news during the COVID-19 pandemic endangers people's lives.

In June 2020, UNESCO reported that "reliable and fake information is spreading around the world to such an extent that some commentators now refer to the new avalanche of misinformation that accompanied the COVID-19 pandemic as disinfodemia" [12], ("misinformation" and "epidemic" together).

The "infodemic" risk has become so acute that the World Health Organization organized, in May 2020, the first "infodemiology" conference in order to study the misinformation created around the new Coronavirus pandemic. While fake news is relatively new and does not kill, infodemia "can kill people if they don't understand what measures must be taken," says Phil Howard, director of the Oxford Internet Institute and author of "The Mashines of Lies" [13].

Intelligence tools, such as the spy satellite imagery, have provided military and political decision-makers with evidence of illegal and possibly criminal activities, such as declining pollution in European and American cities after quarantine, mass incineration in theChinese epidemicaffected cities, mass burials in Iran after the appearance of the virus.

The war of misinformation around the COVID-19 pandemic has been a constant of the atmosphere in which the world has lived since the onset of the disease. In June 2020, the European Commission (EC) issued a joint statement accusing Russia and China of "targeted influence operations and misinformation campaigns around COVID-19 in the EU'. And these campaigns are effective. According to the EC report, misinformation from Russian and Chinese state sources has reached a larger audience on social media in Europe than the reporting on the pandemic carried out by several internal sources.

The coronavirus pandemic will change the nature of the threat perception within the alliance. Since the collapse of the Soviet Union, about three decades ago, NATO has struggled to find a general threat that could keep the nations of the alliance within a common cause. The problem was that these efforts were either expressed too vaguely (as opposed to global disorder or "China's growth"), were too episodic in nature (as in the fight against terrorism), or were geographically limited (such as the threat posed by a revived Russia).

\section{Conclusions}

We are in a dangerous geopolitical moment, which can become even more dangerous through the global depression that is very likely to happen. We are in a geopolitical crisis, but also in an economic and health crisis, a crisis characterized by a lack of leadership, of deliberate lack of vision. Crisis and war represent different facets 
with regard to the degradation of international disputes imposed by irreconcilable interests and actions. War, as a politico-military phenomenon of maximum magnitude, must be redefined from a transdisciplinary, multidisciplinary and pluridisciplinary perspective. For the time being, two competing explanations can be discerned, which are gaining ground: one, in which the lesson is that countries should unite to better defeat COVID-19 and another, in which the lesson is that countries must separate in order to better protect themselves.

In the face of the challenges we are confronted with, we do not know if technology will be our salvation. Today, the information environment is making progress and developing to the detriment of the other instruments of power. Instead of using costly military personnel, states prefer to resort to cyber or psychological attacks.

From this perspective, military science will have to find solutions to the most diverse problems, such as the organization of armies, their endowment, training for combat, the armed combat itself, and, last but not least, the use of armed force in multinational operations of stability and support, humanitarian aid, etc. The results of military science investigations get materialized in the substantiation of the forms, procedures and methods of military action. In fact, there has never been in history a time when knowledge has been unimportant in warfare.

\section{References List}

[1] Bădălan, E., Bogdan, V., Operația contrateroristăa, Editura Militară, București, 2009, pp. 55-71.

[2] Kazhuhorov, George, Security Environment Change: From Aszmmetric to Hybrid Threats, GCM Bulgaria, Sofia, 2016, p. 15.

[3] Joint Publication 5-0, Joint Operating Planning, United States Of America, Joint Chiefs of Staff, Washington, 11 August 2011, pp. III-5, III-7.

[4] Ibidem, pp. 54-56.

[5] Major, Claudia, Möling, Christian, A Hybrid Security Policy for Europe, German Institute for International and Security Affairs, SWP Comments 22, Aprilie 2015, pp.1-2.

[6] Sliwa, Zdzislaw, "Hybrid Warfare"- The Military Security Domain's Considerations, ENDC Occasional Papers, Volume 6, 2017, pp. 15-16.

[7] Ioniță, Liviu, Dimesiunea hibridă a conflictului ruso-ucrainean, în Buletinul UNAp „Carol I”, septembrie 2015, p. 4.

[8] Hybrid Warfare: A New Phenomenon in Europe's Security Environment (2 ${ }^{\text {nd }}$ Edition), European Commission, Jagello 2000, Praha, 2016, p. 13.

[9] Dumitru Cristea, Roceanu Ion, Războiul bazat pe reţea, provocarea erei informaţionale in spaţiul de luptă, p. 108, Bucureşti, Editura Universităţii Naţionale de Apărare „Carol I”, 2005.

[10] https://www.bbc.com/news/world-51984199

[11] https://www.theparliamentmagazine.eu/news/article/pandemic-infodemic-anddisinformation-22294

[12] https://en.unesco.org/campaign/nextnormal

[13] https://www.youtube.com/watch?v=vQDYMUMYAzU

[14] https://euobserver.com/eu-china/148618 